\title{
Regulatory Unilateralism: Arguments for going it alone on climate change
}

Peter Drahos

Australian National University

Christian Downie

University of New South Wales

\begin{abstract}
Climate change is a collective action problem that has often been analysed as a Prisoner's Dilemma. States have an incentive to free ride on the efforts of others. Yet around the globe national and subnational governments are introducing regulatory measures to reduce emissions that can be fairly characterised as unilateral actions. The US and China, the world's two largest emitters, are at the forefront. Indeed the evidence of states beginning to depart from business-as-usual behaviour raises the possibility that the characterizations of climate change as a Prisoner's Dilemma may apply less strongly to the problem and that something else may be starting to happen. Accordingly, this paper considers: (i) to what extent nations are taking unilateral action to address climate change; and (ii) in the context of climate change, which is considered one of the greatest global collective action problems the world has faced, what are the possible economic explanations for nations to act in a unilateral fashion and what are the normative reasons for doing so. We justify regulatory unilateralism on economic, geopolitical and moral grounds, and argue that regulatory unilateralism may offer the best hope of triggering a race to cut emissions. A race rather than prolonged negotiations is what is required at this moment in climate history.
\end{abstract}

\section{Policy Implications:}

- Need to gain a better understanding of the extent and depth of regulatory unilateral action on climate change being undertaken by all states at the national and sub-national levels.

- Need to question whether the Prisoner's Dilemma framework captures the real-world dynamics of the problem of climate change.

- Be aware of the wide range of co-benefits from taking unilateral measures. These go beyond economic benefits to include, for example, the geopolitical benefit a state has from preserving the existing order and avoiding worst-case climate scenarios.

- Unilateral measures should be chosen based on a country's regulatory and innovation capabilities.

Climate change is a collective action problem that has often been analysed as a Prisoner's Dilemma (Soroos 1994; Gardiner S.M. 2001; Newberry 2011). Two decades of international negotiations have produced a climate regime that has had only modest impacts on mitigation (Downie, 2014). Given the strength of the free-rider problem it seems puzzling to consider, as this paper does, the case for 'regulatory unilateralism' in the case of climate change. Even if unilateralism turns out to be an improbable path to climate change mitigation it is worth being sure whether this is actually the case.

Regulatory unilateralism in the context of climate change has not really been explored. Yet there is evidence that states have already taken actions on climate change that can be fairly characterized as 
'regulatory unilateralism'. Moreover, the level of this activity is greater than might be expected if the free rider logic that we described above were to hold tightly or if we were to assume that a Prisoner's Dilemma game perfectly characterized the climate change problem. In other words, the evidence of states beginning to depart from business-as-usual behaviour raises the possibility that these characterizations may apply less strongly to the problem and that something else may be starting to happen.

We analyse regulatory unilateralism in two ways. We begin by considering the extent to which regulatory unilateralism is happening, especially in the US and China, and then shift to a possible economic explanation for why it might be happening. If this explanation is right it also offers a potential normative reason for acting unilaterally, assuming that, all other things being equal, acting to gain an economic benefit gives one a reason for so acting. From there we shift to considering the geopolitical and moral cases for regulatory unilateralism. Ours is an argument by convergence. We find that there are economic, geopolitical and moral reasons for states to adopt policies of regulatory unilateralism.

The next section provides a brief overview of what we mean by regulatory unilateralism. This is followed by a description of some of the unilateral actions being taken around the globe, with an emphasis on the US and China. The remaining sections then examine the arguments for regulatory unilateralism.

\section{Regulatory unilateralism and the structure of free-riding}

One can distinguish between different types of unilateral action. For example, a state can act legally or illegally, or positively (the case of exceeding an agreed standard) or negatively (the case of doing less than an agreed standard). In the case of climate action we are interested in positive unilateralism, the case in which an actor introduces or adjusts standards, rules or a scheme of regulation independently of the actions of other actors, that action not being required under regulatory standards that are authoritative for the actor. For an action to be unilateral it must be voluntary and independent of what another party may or may not do. The motivations for unilateral action will vary. Economic self-interest, reputation, virtue may all motivate unilateral action but as long as an actor's commitment is not contingent upon the action of others it is unilateral.

Our arguments concerning regulatory unilateralism rest on a more detailed account of the structure of the free riding problem facing states in the case of climate change. Where a state is contributing significantly to carbon emissions it is generating a negative externality for all other states and itself. It is a case of reciprocal and reflexive negative externalities (Drahos 2011). As the many volumes of IPCC reports make clear, over time any free riding benefits accruing to states are temporary and will be washed away. Under this structure of reciprocal and reflexive but delayed negative externalities what behaviour do we observe by states? Put succinctly, states have entered into prolonged negotiations over the problem, but the outcomes of those negotiations have fallen well short of what is needed (UNEP 2013). The Paris Agreement is the latest iteration of this prolonged negotiating process. While it is rightly hailed as a milestone, it is important for our purposes to observe that the Paris Agreement is in essence a mix of mandatory proceduralism and sovereign discretion (UNFCCC 2015). States have obligations when it comes to the process of creating and submitting nationally determined contributions (see in particular Article 4), but they have sovereign discretion when it comes to the content of those plans. A state's plans for peaking and reduction of emissions are a matter of national 
determination (UNFCCC 2015). The Paris Agreement urges and invites regulatory unilateralism. A state in acting unilaterally contributes to a change in the structure of the free-riding problem because it reduces the risk of negative externalities for itself and other states and may sometimes generate positive externalities.

If the Prisoner's Dilemma characterization of the problem is correct then the Paris Agreement's reliance on regulatory unilateralism is a profound misstep. It is consistent with each state wanting other states to bear the burden of emissions reduction while it avoids the burden. We have described the problem as a free-riding problem involving reciprocal and reflexive but delayed negative externalities. As the delayed externalities begin to arrive, thereby confirming much of the scientific work, states may well be changing their beliefs about the payoffs of unilateralism. In particular they may be assessing how they can capture co-benefits through implementing unilateral measures.

At this moment in time there is some indeterminacy about how to characterize the present approach of states. A game theoretician could justifiably point to previous failures of the climate talks and say the Paris Agreement's lack of mandatory emission targets is more evidence of payoff rankings by individual states that will see the worse possible outcome for all states. We question this characterization and then develop an argument by convergence for unilateralism that is made up of explanatory and normative components i.e. there is an explanation for why states are changing their behaviour and that change in behaviour can be justified.

\section{Regulatory Unilateralism: is it happening?}

In the international climate change negotiations each major emitter can be seen as holding an emissions chip with which to bargain in return for concessions from other major emitters, much as states hold onto their high tariffs as bargaining chips in order to make sure that they have something to give up in exchange for other states doing the same. There is some evidence that GATT tariff negotiations follow a reciprocity norm (Limao, 2006; Karacaovali and Limao, 2008). Equally one might expect there to be very little unilateralism in the context of climate change. Aside from the loss of bargaining power in climate negotiations, a unilateral shift to renewables by a state might raise energy costs for its industries and risk its carbon intensive industries relocating to states of less stringent regulation (the carbon leakage problem). Yet there is evidence of significant unilateral activity by states going back a number of years.

In order to determine whether regulatory unilateralism is happening it is necessary to first identify which countries have binding international obligations and which do not. Table 1 shows the top 12 emitting countries in descending order of emissions. If we consider the EU a country for the purposes of this discussion, six of the 12 major emitters do not have internationally binding emissions targets. Under the Kyoto Protocol, which expired in 2012, only so-called Annex 1 countries assumed binding targets when they ratified the treaty. The US, which never ratified the Kyoto Protocol, and major developing countries, such as China and India, which are not Annex 1 countries, have never had internationally binding emissions targets. Hence, actions to reduce emissions, for example by the US or China, can be viewed as unilateral actions.

Table 1 Major Emitters 


\begin{tabular}{|l|l|l|l|}
\hline Major emitters & $\begin{array}{l}\text { Internationally } \\
\text { binding emissions } \\
\text { target }\end{array}$ & Reason & Climate actions \\
\hline China & No & Non-Annex 1 & $\begin{array}{l}\text { Yes e.g. emission targets and sub- } \\
\text { national emissions trading }\end{array}$ \\
\hline US & No & $\begin{array}{l}\text { Annex I, but did } \\
\text { not ratify Kyoto }\end{array}$ & $\begin{array}{l}\text { Yes e.g. emission targets and sub- } \\
\text { national emissions trading }\end{array}$ \\
\hline EU & Yes & Annex 1 & $\begin{array}{l}\text { Yes e.g. emission targets and } \\
\text { European-wide emissions trading }\end{array}$ \\
\hline Russia & No & Non-Annex 1 & $\begin{array}{l}\text { Yes e.g. emission targets and } \\
\text { renewable energy targets }\end{array}$ \\
\hline Japan & Yes & $\begin{array}{l}\text { Yes e.g. emission targets and } \\
\text { renewable energy targets }\end{array}$ \\
\hline Korea & Yes 1 & $\begin{array}{l}\text { Yes e.g. emission targets and sub- } \\
\text { national emissions trading }\end{array}$ \\
\hline Canada & Yes & Non-Annex 1 & $\begin{array}{l}\text { Yes e.g. emission targets and national } \\
\text { emissions trading }\end{array}$ \\
\hline Brazil & No & Annex 1 & $\begin{array}{l}\text { Yes e.g. emission targets and sub- } \\
\text { national carbon taxes }\end{array}$ \\
\hline Indonesia & No & Non-Annex 1 & $\begin{array}{l}\text { Yes e.g. emission targets and national } \\
\text { deforestation targets }\end{array}$ \\
\hline Australia & Yes & Non-Annex 1 & $\begin{array}{l}\text { Yes e.g. emission targets and national } \\
\text { deforestation targets }\end{array}$ \\
\hline South Africa & No & $\begin{array}{l}\text { Yes e.g. emission targets and national } \\
\text { emissions trading }\end{array}$ \\
\hline
\end{tabular}

Source: Climate Action Tracker

We begin with the actions of the US and China because together they contribute about 44 percent of global greenhouse gas emissions (the US 16 percent and China 28 percent) (Bi et al., 2014, p. 2). Both countries have historically been on opposing sides of the international climate negotiations and US political leaders have long refused to act without reciprocal actions by China and other large emitters, as epitomised by the 1997 Byrd-Hagel US Senate Resolution, which stated that the US should not be a party to any international agreement which did not mandate commensurate actions for developing countries (United States Senate, 1997).

This is now changing. Regulatory unilateralism has, without any fanfare, been a feature of the Obama Administration. In 2009 it began negotiations with the major car manufacturers over fuel efficiency and carbon pollution standards, standards that eventually took on regulatory form for the entire US industry (The White House 2012). Important also has been the quiet, but large scale standard-setting exercises undertaken by different parts of the US Department of Energy aimed at improving energy efficiency and productivity, as well as ensuring that the US remains a central player in emerging clean energy technology markets (see, for example, Advance Manufacturing Office 2013). In 2013, President Obama outlined his Climate Action Plan to reduce emissions. The most far-reaching component is the Clean Power Plan, administered by the Environmental Protection Agency, which sets carbon pollution standards for existing power plants that are expected to reduce emissions from the power sector by 30 percent by 2030 (The White House, 2013). Other regulatory measures have focussed on energy 
efficiency in the building sector and efforts to preserve existing forests to limit emissions from deforestation (The White House, 2013).

At the sub-national level, almost 30 US states have climate action plans. The state level of energy planning in the US has also become increasingly active since 2000 with many state plans targeting the generation of electricity from renewables (National Association of State Energy Officials, 2013) California has put in place targets to reduce greenhouse gas emissions to 1990 levels by 2020 - a target it is on track to meet - 40 percent below 1990 levels by 2030 and 80 percent below 1990 levels by 2050 (Office of Governor Edmund G. Brown Jr., 2015). It is one of twenty states with state-wide emissions targets (C2ES, 2015). US states have also acted independently of the Federal Government to implement emissions trading schemes. For example, the Regional Greenhouse Gas Initiative, which commenced in 2009, is a regional emissions trading scheme covering nine states in the northeast of the US. In 2013, California also introduced an emissions trading scheme, which aims to link to similar schemes in Canadian provinces (IETA, 2015).

China has also taken a unilateral path. Its $12^{\text {th }}$ Five Year Plan (2011-2015), the 'greenest' in history (Thomson, 2014), has set nation-wide targets to improve energy intensity, carbon intensity, the share of non-fossil fuels in the economy, not to mention a series of pilot emissions trading schemes, all aimed at reducing its contribution to climate change. The most ambitious target is to improve energy intensity, the emissions required to produce GDP, by 16 per cent by 2015 . This follows on from its previous target in its $11^{\text {th }}$ Five Year Plan to reduce emissions intensity by a staggering 20 per cent, which it only narrowly missed, reaching a 19.1 per cent improvement (Leggett, 2011). The same fiveyear plan has set targets to reduce the nation's reliance on coal, which underpins the Chinese energy sector. This includes measures to increase gas production and close down old and inefficient coal plants (Thomson, 2014, p. 1). Further, in 2013 it announced that it would ban the construction of new coal fired power plants in the Beijing, Shanghai and Guandong regions (IEA, 2014, p. 74). The path to a domestic emissions trading scheme is being explored through a series of pilot trading schemes. These schemes are still in the design phase but 'they form an important experiment and learning opportunity that will shape a potential future national ETS' (Zhang et al. (2014, p. 15).

The concrete unilateral actions that we have described are not replacing international coordination and in fact may be helping it. The US and China jointly announced new targets for addressing climate change ahead of the G20 Summit in 2014, with President Obama committing the US to reduce its emissions by 26 to 28 percent below 2005 levels by 2025 and President Xi agreeing, for the first time, to peak Chinese emissions by 2030 (Landler, 2014). Yet, as our discussion of regulatory unilateralism in the previous section shows, this does not negate the fact that the regulatory measures taken have been taken unilaterally.

The practice of regulatory unilateralism has many dimensions because within modern states regulation is much more distributed than centralized. Not to take these levels of regulation into account is to miss the true extent of the climate regulatory unilateralism (Grabosky, 1995; Parker, 2002). For example, hundreds of certification and classification tools relating to the resilience, sustainability and efficiency of urban buildings have been developed around the world, the most well known being LEED (for a review, see van der Heijden, 2014). Cities have become hugely important actors in addressing climate change with, for example, city authorities in Europe under the Covenant of Mayors aiming for a 20\% reduction in $\mathrm{CO} 2$ emissions by 2020 (Azevedo et al 2013). 


\section{The economic rationality of unilateralism?}

Free-rider logic appears to make climate unilateralism irrational, risking one's competitiveness and industries. Is this necessarily true? Within the trade context reciprocity has been important to the process of tariff reduction, with trade negotiators generally arguing against unilateral reductions in trade barriers (Garnaut, 2002, p. 159). Yet from 1983 to 2003 unilateral tariff reductions by developing countries accounted for $66 \%$ of the total share of tariff reduction (World Bank 2005, p. xvi). Was this an outbreak of irrationality?

Baldwin (2010) in analysing this period of unilateralism draws attention to the role of information technology networks in allowing for the coordination of global supply and production chains in which the various parts of a product would be made in different countries and then assembled at an optimal cost location, very often China. This production 'unbundling' facilitated by information technology changes the political economy of protection in developing states. Once states attract investment in the form of production facilities and become exporters of parts and/or final products high protective tariffs no longer make sense. Industrialization that arrives by means of investment erodes the political alliances founded during policy periods based on industrialization through domestic protection. Unilateral action on tariffs by a country is a way of attracting, keeping or competing for business by way of providing the lowest-cost location in global production chains.

So, as a general point, unilateralism may make economic sense for a country, especially in dynamic technology contexts where costs and structures of production are being changed. That said, there are more uncertainties surrounding the economic case for climate regulatory unilateralism. In the case of tariffs, the action required is one of removing a barrier (a case of deregulatory unilateralism) whereas with climate unilateralism states can choose from an array of positive actions that include market-based carbon trading schemes, carbon taxes, feed-in tariffs, tax concessions, energy efficiency standards and encouraging the adoption of voluntary standards in various sectors.

The economic case for climate regulatory unilateralism has some support in Michael Porter's (1990) theory of competitive advantage. In setting out the determinants of national competitive advantage - factor conditions, demand conditions, related and supporting industries and firm strategy, structure and rivalry - Porter argued that governments have a legitimate role to play in shaping the context and institutional structure around companies to create an environment that stimulates companies to gain competitive advantage (Porter, 1990, p. 87). One role is to implement strict environmental regulations. Whereas environmental goals and industrial competitiveness are often viewed as a tradeoff, Porter and Linde (1995, p. 98) showed that 'properly designed environmental standards can trigger innovation', which not only lowers the cost of complying with the environmental regulations, but can also lead to absolute advantages over firms in other countries not subject to the same regulations. This is because some firms will innovate in response to regulations by being smarter about how to deal with pollution, but more importantly, by simultaneously innovating to improve the product and the production process. For example, in Japan in 1991, Hitachi responded to a new recycling law by redesigning products to reduce disassembly time. As a result, the number of parts in a washing machine fell 16 percent and the number of parts in a vacuum cleaner fell 30 percent (Porter and Linde, 1995, pp. 101-102).

Most importantly, in the context of regulatory unilateralism, the competitive advantage thesis shows that when environmental regulations anticipate standards that are likely to globalise, they give a 
nation's companies an early mover advantage in international markets. For instance, German firms gained an early mover advantage developing less packaging intensive products following the German Government's implementation of recycling standards ahead of many other nations (Porter and Linde, 1995). With recent forecasts suggesting that renewable energy will account for 50 per cent of installed power generation capacity by 2030, up from 28 per cent in 2012, and demand for products that are more energy efficient, such as fuel efficient cars on the rise, there are strong economic arguments for countries to take a regulatory unilateral approach to climate change (BNEF, 2013). For example, China's renewable energy targets have already led its companies to be world leaders in solar PV manufacturing, out competing US and European suppliers (IEA, 2013, p. 211).

Porter's arguments concerning competitive advantage have been criticized (Klein, 2001; O'Shaugnessy, 2006). However the case studies supporting the theory suggest that broader climate regulatory unilateralism may deliver economic benefits. States still face uncertainties and information problems in using regulatory unilateralism as a strategy for building competitive advantage. Regulatory unilateralism has to be complemented by, for example, an innovation system that has the capability of shifting to new kinds of innovation. Raising the regulatory bar as a way of stimulating environmental innovation in Germany draws on traditions and strengths of German industry, such as a highly skilled labour force and a strong commitment to industry-funded research that do not necessarily have parallels in other countries. (Hall and Soskice, 2001, p. 25-26) Would the same strategy for building comparative advantage in environmental innovation work as well in Poland where companies do not have the same engineering skills, the patent portfolios or the marketing strategies to convince consumers to pay more? Polish policy makers may well come to the view that they should steer a different course on environmental regulation, exploiting the price advantages conferred by Poland's domestic coal supplies. Regulatory unilateralism has to be carefully considered within a country's economic context.

Ultimately, the economic case for climate regulatory unilateralism has to pass some threshold test of plausible benefits, but the fact that we are seeing unilateral behaviour within large emitting states suggests they perceive some benefits. Focussing on China, its goal of changing its approach to economic growth was formally announced at the Seventeenth National Congress of the Communist Party of China and given the label of 'ecological civilization' (Oswald, 2014). This change in direction is hardly surprising. Air pollution has become a major killer of Chinese citizens and may well be the biggest (UNDP, 2013, p. 30). China's five year plans for the environment have not been successful with a World Bank (2007) study showing that its $10^{\text {th }}$ five year plan failed to meet 10 out of 13 of its goals for reducing air and water pollution. In a measure of how seriously it is taking environmental goals, the central government has been working to improve information transparency in the environmental field (Zhang, 2014). The link between air pollution and the use of coal to generate electricity has led to a co-benefit argument in favour of China doing more on reducing its $\mathrm{CO} 2$ emissions (Zheng et al, 2011). By reducing its use of fossil fuels China would also be reducing the emission of other pollutants, especially $\mathrm{SO}$, thereby gaining measurable short term benefits in terms of better air quality and addressing other environmental problems such as acid rain.

Regulatory unilateralism may also allow China to capture other types of co-benefits. The multinationals that have used China as the final assembly point for many of their products have benefited from China's comparative advantage in a large low cost labour market (Athukorala and Yamashita, 2009). The gains to China of this model have been foreign investment and industrialization 
albeit with heavy environmental costs. However, if global production as a value chain is analysed we see China's share of that value chain is small. It is the owners of Google's and Microsoft's intellectual property rights that capture most of the economic rents from global production chains (Dedrick et al, 2010).

For China climate regulatory unilateralism may be one way in which it can encourage the growth of consumption in its internal market. The basic idea would be to use the Porter logic of setting high environmental standards, while investing more in R\&D in climate-related technologies. There is some evidence that China is following this strategy, setting regulatory frameworks for low carbon technologies such as electric vehicles, a product sector in which it has become the world's number one producer (Watson et al, 2015).

The core idea of regulatory unilateralism for China is to think broadly and creatively about the cobenefits of such unilateralism, focusing in particular on the capacity of its vast internal market to deliver those benefits. We are not suggesting that regulatory unilateralism would inevitably trigger a crossover into a new greener economy, but at the same time we should not be blind to the possibility that China could use unilateralism to help it make this great economic crossing. The co-benefit argument also applies to India. For both China and India climate regulatory unilateralism offers the chance to create internal markets in innovation with all that implies about setting and capturing technical standards in the climate sensitive markets of the future.

Climate unilateralism may also deliver regulatory models that end up diffusing globally, such scale of diffusion being a characteristic of regulatory capitalism (Levi-Faur and Jordana, 2005). The unilateral construction of a model, if successful, may seduce other nations into the act of regulatory modelling (Braithwaite and Drahos, 2002, p. 32). There is an abundant literature on the spread of emissions trading based on its initial success at addressing SO2 emissions in the US (Stavins, 1998) to a worldwide phenomenon that has been taken up across the globe, including in China (Jotzo and Löschel, 2014). The rationality of unilateral trade liberalization has been defended on the basis of its potential modelling effects (Bhagwati, 2002; Garnaut, 2002).

Our last point concerning the economics of climate unilateralism relates to its trade and market integration potential. For example, Japan is a world leader in the development of climate change mitigation technologies (Dechezleprêtre et al, 2011). A Chinese unilateralism that accelerated the absorption of these technologies would benefit both parties and offers the intriguing possibility of a green East Asian capitalism.

\section{Is it geopolitically prudent?}

There is an increasing recognition among policymakers that climate change poses not just economic challenges, but serious geopolitical ones as well. In 2014, the US Department of Defence warned that climate change will increase the risk of conflicts over water, food and other resources (Department of Defense of USA, 2014). Scientific studies suggest that the $2^{\circ} \mathrm{C}$ plus world we are heading into will be a world of crises. (Stocker et al., 2013). As others have noted, crises have the potential to transform the behaviour of states (Zartman, 2003). There is a long list of examples where international crises, such as the oil shocks in the 1970s, or financial crises over the decades, have led states to rush to establish new rules and institutions, such as the International Energy Agency or new fora for financial cooperation such as the G20. 
It is an open question as to when the increase in the frequency and severity of natural disasters will usher in an era of climate mobilization. As the evidence and probability of catastrophic consequences of climate change mount each major emitter has an increased incentive to cooperate because without that cooperation politically credible action within the domestic sphere to safeguard the security and economic interests of a state begin to decline. The argument for acting unilaterally before this greater cooperation point is reached is twofold.

First if the evidence points to the very survival of states being threatened by the global scale of climate change then survival would become a primary motivation of any state so convinced by the evidence. It follows that it would be rational to act to bring about cooperation as quickly as possible. If, as we suggested in the previous section, unilateralism holds the potential of triggering modelling effects then it becomes geopolitically rational for a state to act in that way. Saving itself now depends on persuading other states to act reciprocally and so any path to encouraging reciprocity becomes important. A second reason for adopting climate regulatory unilateralism lies in the geopolitical benefits of being seen as a global leader during times of crisis. A state that has acted in anticipation of crisis has more chance of being followed by other states than being a follower, has more chance of being a rule setter rather than a rule taker. In this position a state has a much better chance of shaping global responses to climate interests in ways that attend to its other interests, such as sovereignty and domestic stability.

However, international relations scholars typically argue that unilateralism imposes significant costs on states. There are two main arguments that apply in the case of climate change. First, liberal institutionalists argue that unilateralism threatens the efficiency gains that can result from institutionalised cooperation (Brooks and Wohlforth, 2005, pp. 513-514). This argument has some weight in the context of security, but in the case of climate unilateralism we are dealing with actions aimed at a reducing rising negative externalities that affect all states. With climate unilateralism a state is not undermining the climate regime by doing less than agreed, but rather strengthening it by doing more. Unilateralism in the climate context allows a state to be a leader in improving agreed standards. Importantly, acting unilaterally does not foreclose on the possibility of a multilateral agreement and may be one stepping stone to such an agreement.

Second, international relations scholars have argued that U.S. unilateralism undermines the legitimacy of the liberal international order (Hurd, 2007). Going it alone on climate change, like on other significant geopolitical issues, it is argued, undermines the institutions that socialise actors to the existing order and leads them to internalise the norms of the system. Yet as Brooks and Wohlforth (2005, p. 517) point out 'some kinds of unilateral actions threaten legitimacy more than others'. And, this is precisely the case with climate change. Some unilateral actions may enhance the legitimacy of the existing order, especially where they produce public goods consistent with existing international norms. Unilateral action has often played a critical role in establishing international environmental standards. For example, the threat by the US to unilaterally impose double-hull standards on oil tankers entering its ports helped to create the 1973 MARPOL convention and the later Protocol (Bodansky, 2000, p. 344). Smaller powers would also be likely to follow to the extent that they are convinced that the goals of the US or another major power are worthy in themselves and serve the 'greater good' (Cooper et al., 1991, p. 398). Rather than undermining the legitimacy of a nation, regulatory unilateralism on climate change could well enhance its geopolitical standing and that of the existing international system. 


\section{Is it morally justified?}

There is also a moral case for regulatory unilateralism to be considered. The reciprocal negative externalities of climate change are progressively coming into focus. We already have estimates that climate change is currently causing 150,000 deaths and 5 million incidents of disease each year in some of the poorest countries (McMichael et al, 2004). As such, the actions of nations can be considered morally in terms of those effects.

First, unilateral climate measures can be assessed along the same lines that scholars assessed the morality of unilateral nuclear disarmament during the Cold War. That is, the human lives lost or saved (Lackey, 1985, p. 154). In the 1980s, the dominant view in the US Government was that a nuclear arsenal acts as a deterrent against another nation using their weapons: the so-called doctrine of mutually assured destruction (Schelling, 1966). As a result, US policymakers argued that unilateral nuclear disarmament should not be undertaken because it would have undermined the deterrence of nuclear war with the Soviet Union. However, as many scholars pointed out, this is hard to sustain morally. For example, Lackey (1985, p. 154) argued that if one 'one assumes that human lives lost or saved is the principal criterion by which nuclear weapons policies should be measured' it follows that unilateral nuclear disarmament is morally superior because the casualties from a one-sided nuclear attack developing under a policy of unilateral disarmament are much less than under a nuclear deterrence strategy where both nations employ their nuclear arsenal. Others came to similar conclusions (see, for example, Goodin, 1985).

At a general level, it is the same for climate change. To the extent that a unilateral reduction in greenhouse gas emissions by any nation reduces the number of deaths and incidence of disease caused by climate change it is morally superior to act, than not to. One critique of this position is that it assumes that a reduction in emissions would reduce death and disease. And some scholars argue this is far from certain. For example, Posner and Sunstein (2008, p. 1575) argue that the effect of one or a few nations taking action alone to reduce emissions would be very small given the large existing stock of greenhouse gases in the atmosphere. However, this confuses the moral correctness of an action with its scale effects. We do not, for example, question the moral correctness of actions by a few brave individuals that have saved only a small number of people from death in concentration camps. Even if unilateral action is only taken by a handful of small nations, which contribute very little to changing the finality of climate change, to the extent that it reduces the likelihood of death and disease for even one person, then unilateral action must be morally superior to not acting. And, if a large state takes action, such as the US or China, which contribute 16 per cent and 28 per cent of global greenhouse gas emissions respectively, then the impact on death and disease would be greater still.

Second, unilateral actions could also open up moral pathways to reciprocal action by other nations. One way would be to help to promote the development of 'prohibitionary norms' that make some actions morally unacceptable, such as a national decision not to reduce emissions. Constructivist international relations scholars argue that one of the reasons nuclear and chemical weapons are not used is because of the odium that has attached to them. Over time particular social and cultural meanings became associated with these weapons, which in turn created prohibitionary norms that rendered their use unacceptable (see, for example, Price and Tannenwald (1996). Regulatory unilateralism, especially by large states, could help to promote similar prohibitionary norms around 
particular climate change policies, for example, weak emissions targets, a reliance on coal, or rampant deforestation.

\section{Conclusion: toward climate regulatory unilateralism}

As we have seen, the US and China, the world's two largest emitters, are at the forefront of what we have termed regulatory unilateralism. While acknowledging there is some indeterminacy about the matter we have suggested that the evidence of regulatory unilateralism point to states beginning a process of re-thinking the payoffs of free-riding. The structure of free-riding in the case of climate emissions - reciprocal and reflexive but delayed negative externalities - is consistent with our claim. As the negative externalities begin to arrive states start to examine what they can do jointly and where they can capture other benefits from moving unilaterally they do so. On this interpretation of state behaviour the Paris Agreement is an important step in climate change negotiations because it is encouraging states to do what in the final analysis will be key to meeting the 2 degree goal - a wide and rapid array of unilateral actions by states.

Our analysis has implications for policy makers in a post-Paris world. First, policymakers need to gain a better understanding of the extent and depth of unilateral action being undertaken by all states. The Prisoner's Dilemma has been a dominant framework for analysing climate change, but our question is does it capture the real-world dynamics of the problem? In much the same way that states that misread the importance of unilateral tariff liberalization in a world of globalized supply chains would also have lost economic opportunities, so a misreading of the extent and importance of climate unilateralism will also likely incur opportunity costs.

Second, policymakers should not read the co-benefits of climate unilateralism narrowly. As we saw with China, there are obvious co-benefits in the form of reduced pollution, but the range of co-benefits is much wider than these obvious cases. While for reasons of space we have only sketched the geopolitical and moral justifications for climate unilateralism, it is clear that part of the geopolitical case for acting unilaterally comes from preserving the benefits a state has from the existing order and avoiding a descent into worst case climate scenarios of survival governance. Properly understood this co-benefit takes the form of preserving existing gains and avoiding losses.

The correctness of the moral argument for unilateralism is independent of any co-benefits it might generate, but worth noting is that moral unilateralism may act as signal to those in the investment community who have been persuaded on moral grounds to divest from fossil fuel and invest in renewables. Moral unilateralism in the framework of game theory might be seen as having a sucker's payoff, but the growing transnational influence of the divestment movement (Ayling and Gunningham 2015) suggests that unilateralism helps to forge a community of like-minded investors looking for responsible investment opportunities.

With regulatory unilateralism we are, as section 2 made clear, dealing with a class of positive actions to secure a possibly wide range of benefits. This does raise the issue of which unilateral acts and their linked co-benefits a state should choose. Clearly, this is a contextual matter. The choices available to small island economies will be different compared to countries with large internal domestic markets, such as China or India, or energy importing but export dependent countries, such as South Korea. Since the set of feasible choices will be affected by a country's regulatory and innovation capabilities a detailed assessment of those capabilities is required. In short, climate unilateralism and its co- 
benefits should be part of national technology mapping and planning exercises. Countries with large or growing car industries, for example, would want to consider the way in which climate unilateralism might re-shape their respective industries.

If we accept that in an ideal world cooperative regulatory multilateralism represents the most effective way to address a real world emergency then this suggests that states should choose unilateral regulatory measures that open up pathways to reciprocal action while avoiding those that limit or jeopardize cooperation. For example, the creation of carbon markets has been a bottom-up and often unilateral process (Newell et al 2013) that might lead to the ideal of global carbon market. Geo-engineering would on present knowledge be a high-risk unilateral intervention with uncertain consequences (Barrett, 2008).

In this period of the climate change problem the best hope is for states, especially the major emitters to conclude that they are not in a Prisoner's Dilemma, but rather in a period where positive unilateralism can help them capture co-benefits of economic reward, geopolitical stability and virtue. There is everything to be gained from regulatory unilateralism.

\section{Notes}

We would like to thank the Editor and two anonymous reviewers for their comments on how to improve the arguments in this paper. We also acknowledge the feedback of participants at the Law and Society Association Annual Conference, Seatle, 2015, and the Global Sustainability Working Group at MIT, Cambridge, 2015.

\section{References}

Advance Manufacturing Office, US Department of Energy, (2013) Impacts: Results for CY 2010 available from http://www1.eere.energy.gov/manufacturing/about/pdfs/impacts2010_full_report.pdf [accessed 18 April 2016].

Athukorala, P. and Yamashita, N. (2009) 'Global Production Sharing and Sino-US Trade Relations', China \& World Economy, 17 (3), pp. 39-56.

Ayling, J. and Gunningham, N. (2015) 'Non-state governance and climate policy: the fossil fuel divestment movement', Climate Policy, pp. 1-15.

Azevedo, I., Delarue, E. and Meeus, L. (2013) 'Mobilizing cities towards a low-carbon future: Tambourines, carrots and sticks', Energy Policy, 61, pp. 894-900.

Barrett, S. (2008) 'The Incredible Economics of Geoengineering', Environmental and Resource Economics, 39, pp. 45-54.

Baldwin, R. (2010) 'Unilateral Tariff Liberalisation', The International Economy, Journal of The Japan Society of International Economics, 14, pp. 10-43.

Bhagwati, J. (2002) 'Introduction: The unilateral freeing of trade versus reciprocity', in Bhagwati, J. (ed.), Going Alone: The Case for Relaxed Reciprocity in Freeing Trade. Cambridge: MIT Press, pp. 1-31.

Bi, J., Young, O.R., Costanza, R., Liu, L., Kasperson, R., Qi, Y., Guttman, D., Jiang, K., Mazmanian, D., Zhang, S., Zhang, J., Osherenko, G., Percival, R., Zhang, B., Wang, H., He, P., and Liu, M. (2014) 'Same dream, different beds: Can America and China take effective steps to solve the climate problem?' Global Environmental Change, 24, pp. 2-4.

Bloomberg New Energy Finance (BNEF) (2013) Global Renewable Energy Market Outlook, Bloomberg, London. Available from: http://about.bnef.com/presentations/global-renewable-energymarket-outlook-2013-fact-pack/ [Accessed 3 February 2016]. 
Bodansky, D. (2000) 'What's so bad about unilateral action to protect the environment?', European Journal of International Law, 11 (2), pp.339-347.

Braithwaite, J. and Drahos, P. (2000) Global Business Regulation. Cambridge: Cambridge University Press.

Brooks, S.G. and Wohlforth, W.C. (2005) 'International Relations Theory and the Case against Unilateralism', Perspectives on Politics, 3, pp. 509-524.

Center for Climate and Energy Solutions (C2ES) (2015) Greenhouse gas emissions targets. Available from: http://www.c2es.org/us-states-regions/policy-maps/emissions-targets [Accessed 3 February 2016].

Climate Action Tracker (2015) Available from: http://climateactiontracker.org/global.html [Accessed 3 February 2016].

Cooper, A.F., Higgott, R.A. and Nossal, K.R. (1991) 'Bound to Follow? Leadership and Followership in the Gulf Conflict', Political Science Quarterly, 106, pp. 391-410.

Dechezleprêtre, A., Glachant, M., Haščič, I., Johnstone, N. and Ménière, Y. (2011) 'Invention and Transfer of Climate-Mitigation Technologies: A Global Analysis', Review of Environmental Economics and Policy, 5, pp. 109-130.

Dedrick, J., Kraemer, K.L. and Linden, G. (2010) 'Who profits from innovation in global value chains?: a study of the iPod and notebook PCs', Industrial and Corporate Change, pp. 1-36. doi:10.1093/icc/dtp032

Department of Defense of USA (2014) Quadriennial Defense Review 2014. Available from: http://archive.defense.gov/pubs/2014_Quadrennial_Defense_Review.pdf [Accessed 3 February 2016].

Downie, C. (2014) The Politics Of Climate Change Negotiations: Strategies and Variables in Prolonged International Negotiations. Cheltenham: Edward Elgar.

Drahos, P. (2011) 'Bargaining over the Climate: Lessons from Intellectual Property Negotiations' Climate Law, 2, pp. 1-17.

Gardiner S.M. (2001) 'The real tragedy of the commons' Philosophy \& Public Affairs 30, pp. 387-416.

Garnaut, R. (2002) 'Australia: A Case Study of Unilateral Trade Liberalization', in Bhagwati, J. (ed.), Going Alone: The Case for Relaxed Reciprocity in Freeing Trade. Cambridge: MIT Press, pp. 139166.

Goodin, R.E. (1985) 'Nuclear Disarmament as a Moral Certainty', Ethics, 95, pp. 641-658.

Grabosky, P. (1995) 'Using Non-Governmental Resources to Foster Regulatory Compliance', Governance, 8 (4), pp. 527-550.

Hall, P.A. and Soskice, D. (2001) 'An introduction to varieties of capitalism', in Hall, P. and Soskice, D. (eds) Varieties of Capitalism: The Institutional Foundations of Comparative Advantage. Oxford: Oxford University Press, pp. 1-68.

Hurd, I. (2007) 'Breaking and Making Norms: American Revisionism and Crises of Legitimacy', International Politics, 44, pp. 194-213.

International Energy Agecy (IEA) (2013) World Energy Outlook 2013. Available from: http://www.worldenergyoutlook.org/weo2013/ [Accessed 3 February 2016].

International Energy Agecy (IEA) (2014) Energy Technology Perspectives 2014. Available from: http://www.iea.org/etp/etp2014/ [Accessed 3 February 2016].

International Emissions Trading Association (IETA) (2015) The world's carbon markets: a case study guide to emissions trading. Available from: https://ieta.memberclicks.net/worldscarbonmarkets [Accessed 3 February 2016].

Jotzo, F. and Löschel, A. (2014) 'Emissions trading in China: Emerging experiences and international lessons', Energy Policy, 75, pp. 3-8.

Karacaovali, B. and Limao, N. (2008) 'The clash of liberalizations: preferential vs. multilateral trade liberalization in the European Union', Journal of International Economics, 74, pp. 299-327. 
Klein, J. (2001) 'A critique of competitive advantage'. Paper presented at Critical Management Studies Conference, Manchester, July 2001. Available from: http://www.mngt.waikato.ac.nz/ejrot/cmsconference/2001/Papers/Strategy/KleinACritiqueofCompetitiveAdvantage.pdf. [Accessed 3 February 2016].

Lackey, D.P. (1985) 'Immoral Risks: A Deontological Critique of Nuclear Deterrence', Social Philosophy and Policy, 3, pp. 154-175.

Landler, M. (2014) 'U.S. and China Reach Climate Accord After Months of Talks', The New York Times, 11 November. Available from:http://www.nytimes.com/2014/11/12/world/asia/china-us-xiobama-apec.html?_r=0. [Accessed 3 February 2016].

Leggett, J. (2011) China's Greenhouse Gas Emissions and Mitigation Policies. Washington, D.C.: Congressional Research Service.

Levi-Faur, D. and Jordana, J. (2005) 'The Rise of Regulatory Capitalism: The Global Diffusion of a New Order', The Annals of the American Academy of Political and Social Science, 598, pp. 200-217.

Limao, N. (2006) 'Preferential trade agreements as stumbling blocks for multilateral trade liberalization: evidence for the United States', American Economic Review, 96, pp. 896-914

McMichael. A.J, et al. (2004) 'Climate change'. in Ezzati, M., Lopez, A.D., Rodgers, A. and Murray, C.J. (eds), Comparative quantification of health risks: global and regional burden of disease due to selected major risk factors, Vol. 2. Geneva: World Health Organization.

Newberry, D. (2011) 'Oil shortages, climate change and collective action', Philosophical Transactions of the Royal Society 369 pp. 1748-1761.

Newell, R.G. Pizer W.A. and Raimi, D. (2013) 'Carbon Markets 15 Years after Kyoto: Lessons Learned, New Challenges' Journal of Economic Perspectives, 27, pp. 123-146.

National Association of State Energy Officials (2013) An Overview of Statewide Comprehensive Energy Plans: From 2002 to 2011.2 Available from: https://www.naseo.org/Data/Sites/1/naseo_39_state_final_7-19-13.pdf [Accessed 3 February 2016].

Office of Edmund G. Brown Jr. (2015) 'Governor Brown establishes most ambitious greenhouse gas reduction target in North America', Press release, 29 April. Available from: http://gov.ca.gov/news.php?id=18938 [Accessed 3 February 2016].

Oswald, J.P.F. (2014) 'What does eco-civilization mean?', The China Story, 4 September. Available from: https://www.thechinastory.org/2014/09/what-does-eco-civilisation-mean/ [Accessed 3 February 2016].

O'Shaughnessy, N.J. (1996) 'Michael Porter's "Competitive Advantage" Revisited', Management Decision, 34 (6), pp. 12-20. http://dx.doi.org/10.1108/00251749610145889

Parker, C. (2002) The Open Corporation. Cambridge: Cambridge University Press.

Porter, M.E. (1990) 'The Competitive Advantage of Nations', Harvard Business Review, 68, pp. 73-93.

Porter, M.E. and Linde, C.v.d. (1995) 'Toward a New Conception of the Environment-Competitiveness Relationship', The Journal of Economic Perspectives, 9, pp. 97-118.

Posner, E. and Sunstein, C. (2008) 'Climate Change Justice', Georgetown Law Journal, 96, pp. 15651612.

Price, R. and Tannenwald, N. (1996) 'Norms and Deterrence: The Nuclear and Chemical Weapons Taboos', in Peter J. Katzenstein (ed.), The Culture of National Security: Norms and Identity in World Politics. New York: Columbia University Press.

Schelling, T.C. (1966) The Diplomacy of Violence. New Haven: Yale University Press, pp. 1-34.

Soroos M.S. (1994) 'Global change, environmental security and the Prisoner's Dilemma', Journal of Peace Research, 31, pp. 317-332.

Stavins, R.N. (1998) 'What Can We Learn from the Grand Policy Experiment? Lessons from SO2 Allowance Trading', The Journal of Economic Perspectives, 12, pp. 69-88.

Stocker, T.F., D. Qin, G.-K. Plattner, M. Tignor, S.K. Allen, J. Boschung, A. Nauels, Y. Xia, V. Bex and Midgley, P.M. (2013) Climate Change 2013: The Physical Science Basis. Contribution of 
Working Group I to the Fifth Assessment Report of the Intergovernmental Panel on Climate Change. Cambridge: Cambridge University Press.

The White House (2013) The President's Climate Action Plan. Executive Office of the President, Washington D.C.

The White House (2012) 'Obama Administration Finalizes Historic 54.5 MPG Fuel Efficiency Standards'. Press release, 28 August. Available from: https://www.whitehouse.gov/the-pressoffice/2012/08/28/obama-administration-finalizes-historic-545-mpg-fuel-efficiency-standard [Accessed 3 February 2016].

Thomson, E. (2014) 'Introduction to special issue: Energy issues in China's 12th Five Year Plan and beyond', Energy Policy, 73, pp. 1-3.

UNEP, (2013) 'The Emissions Gap Report'. United Nations Environment Program, Nairobi.

UNFCCC, (2015) 'Adoption of the Paris Agreement'. United Nations Framework Convention on Climate Change, Paris. Available from: https://unfccc.int/documentation/documents/advanced_search/items/6911.php?priref=600 008831 [Accessed 28 April 2016].

United States Senate (1997) Senate Resolution 98, 105th Congress. Ist Session.

van der Heijden, J. (2014) Governance for Urban Sustainability and Resilience: Responding to Climate Change and the Role of the Built Environment. Cheltenham: Edward Elgar.

Watson, J., Byrne, R., Ockwell, D. and Stua, M. (2015) 'Lessons from China: building technological capabilities for low carbon technology transfer and development', Climatic Change, 131, pp. 387-399.

World Bank (2007) 'Cost of pollution in China: economic estimates of physical damages'. Washington, D.C. Available from:http://documents.worldbank.org/curated/en/2007/02/7503894/costpollution-china-economic-estimates-physical-damages [Accessed 3 February 2016].

World Bank (2005) 'Global Economic Prospects: Trade, Regionalism and Development'. Washington, D.C. Available from: http://siteresources.worldbank.org/INTGEP2005/Resources/gep2005.pdf [Accessed 3 February 2016].

Zartman, W. (2003) 'Negotiating the Rapids: The Dynamics of Regime Formation', in Spector, B. and Zartman, W. (eds), Getting It Done: Postagreement Negotiation and International Regimes. Washington, D.C.: United States Institute of Peace Press, pp. 13-50.

Zhang, D., Karplus, V.J., Cassisa, C. and Zhang, X. (2014) 'Emissions trading in China: Progress and prospects', Energy Policy, 75, pp. 9-16.

Zheng, X., Zhang, L. and Yu, Y. (2011) 'On the nexus of SO2 and CO2 emissions in China: the ancillary benefits of $\mathrm{CO} 2$ emission reductions', Regional Environmental Change, 11, pp. 883-891.

\section{Author Information}

Peter Drahos is a Professor in the RegNet School of Global Governance and Regulation, Australian National University and holds a Chair in Intellectual Property, Queen Mary University of London.

Christian Downie is a Vice Chancellor's Postdoctoral Fellow at the University of New South Wales and a Visiting Fellow at the Australian National University. 